\title{
Mixed-Integer Linear Programming Model for Production Planning: A Case Study at Sawn Timber Production
}

\author{
Octavia Riskadayanti *, Muhammad Hisjam, Y Yuniaristanto \\ Department of Industrial Engineering, Universitas Sebelas Maret, Indonesia \\ Jl. Ir Sutami No.36 A, Pucangsawit, Jebres, Surakarta, Jawa Tengah, Indonesia \\ * Corresponding author: octaviariskadayanti@gmail.com
}

\section{ARTICLE INFO}

Article history

Received February 25, 2020

Revised August 2, 2020

Accepted August 8, 2020

Available Online August 30, 2020

Keywords

Sawmill

Production Planning

Mixed-Integer Linear Programming

Optimization

\begin{abstract}
The sawmill industry is an industry that processes logs into sawn timber products through several processes to maximize profits and meet customer demand. The process involves essential operations that have to be coordinated to get the desired product with the available resources optimally. Efficient operations can be achieved through optimal production planning by considering some factors to optimize the number of sawn timber product combinations. Optimal production planning is expected to have an impact, such as reducing the use of raw materials that can affect inventory and procurement. In this research, the author has developed a mathematical model for production planning to determine the optimal number of sawn timber product combinations. Problems were solved using mixed-integer linear programming methods with mathematical modeling that aimed for maximizing profit. Production costs, raw material costs, and purchasing costs were critically considered in this mathematical modeling. The result showed that using the developed model could integrate the factors above, fulfill the demand, and increase company income.
\end{abstract}

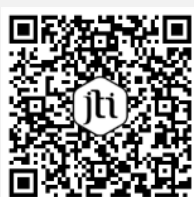

This is an open-access article under the CC-BY-SA license.

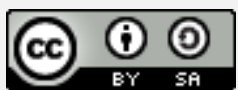

\section{Introduction}

The sawmill industry is an industry that processes logs into various sizes of sawn timber that is ready for use. The processing of logs is through various stages such as the cleavage, ripping process, and cutting process [1], [2], [3]. The processing of log into sawn timber starts from the classification of the log conforming to length and diameter [4], [5]. Then, the first cutting process of the log to sawn timber wood called primary saw produces cant and flitch. In this process, the cant and flitch are cut into sawn timber in various dimensions at the end [6], [7]. The conversion process into various sizes of sawn timber is intended to maximize profits and fulfill customer demand [8].

The conversion process involves a critical operation that has to be coordinated to obtain the desired product with the available resources optimally. Efficient operation can be achieved through optimal production planning by considering the lumber recovery factor or lumber yields [8], [9], [10]. The lumber recovery factor is the percentage or ratio of the volume of sawn timber product output to the volume of log input that is processed 
in the sawmill [8], [11], [12]. Several factors that affect the system of production processes and lumber recovery factor are The number of sawn timber products combination based on customer demand and the raw materials, the availability of raw materials based on the diameter and length of the log, the logs processing into sawn timber products, and the machine tools [5], [13], [14], [15]. Therefore, production planning by considering the factors above needs to be integrated appropriately to achieve the goal of proper system and efficient production [6], [16]. Furthermore, by optimizing the production planning, the sawmill industry can reduce the amount of log used, log cost, and log waste [17], [18], [19], [20], [21].

In production planning, the solutions model can be obtained from linear programming models [22]. Linear programming is a model of analysis that can be applied in using limited resources to obtain the optimal solution, such as maximum profit or minimum cost in a mathematical model [23], [24]. Several previous studies apply linear programming models for production planning sawmill problems. Alvarez and Vera [25] present mathematical modeling that considers an annual planning period and solving some uncertainties. Farrell and Maness [26] examine a mixed-integer linear programming model to maximize the wood manufacturing process. Koch, et al. [27] study integer linear programming models to reduce the cutting process costs in the sawmill industry. Lindner, et al. [28] propose a study to minimize the production costs by optimizing engine settings in sawmill operation. Vanzetti, et al. [6] suggest an optimization approach for multi-period production planning in the sawmill. In addition, Broz, et al. [29] highlight a goal programming application of several objectives: maximizing profit, minimizing loss of material, minimizing inventory, and minimizing the unmet demand in making decisions in a sawmill. The previous studies show that the linear programming model can help the sawmill industry solve problems in sawmill production planning and improve production planning.

In this research, the method used was mixed-integer linear programming with the goal of profit maximization. The model used was a model by Vanzetti, et al. [6] with some modifications to adjust it with the company's actual conditions. The purpose of the model was to determine the optimal number of sawn timber products by considering the efficiency of processing logs into sawn timber products. Modifications made were in the objective function and the addition constraint function regarding the sawing machine's production capacity. The addition of this constraint function was intended so that all elements in production planning could be simultaneously assessed according to the industry's limits. This research implemented ILOG CPLEX to process the data. One of the advantages of using ILOG CPLEX is the Optimization Programming Language (OPL) as Algebraic Modeling Languages (AML) that is believed to make the coding process easier and simpler [30]. This study contributes to production planning by developing a sawn timber production planning model by considering machine capacity.

The paper was structured as follows; Problem statement, assumptions, notation, mathematical modeling, case study, and sensitivity analysis procedure were described in Section 2; whereas Section 3 presented the results and discussion. Section 4 contained conclusions and suggestions.

\section{Methods}

In this section, the article describes problems, assumptions, and mathematical models. This paper modified the proposed model proposed by Vanzetti, et al. [6]. a detailed description is presented in the next subsection. 


\subsection{Problem Statement and Assumptions}

During the production process, the primary key that has to be maximized is the production planning to determine the type of sawn timber products and the volume. Sawn timber products consist of various types and sizes. Various assumptions were discussed in this research. 1) There is a concept regarding the primary order and side order as sawn timber products. Main order and side orders are the sawn timber products obtained after operating through three production processes. Main orders are stacks of sawn timber products that are ordered from customers. Side orders are stacks of sawn timber products that are non-ordered from customers. Non-order products are products that could be stored and sold when an order is placed. The purpose of non-order products is to maximize the processing logs into sawn timber products, so the wood waste from the production process can be reduced. 2) The type and size of the primary order and the side order adjusted to the products. 3) The stages of the production process from log to sawn timber products are carried out directly. This assumption is used to systematize, integrate and aggregate the sawing process. In this study, the model developed was a model for finding the optimal number of combinations of sawn timber products that correspond to the primary order and the side order.

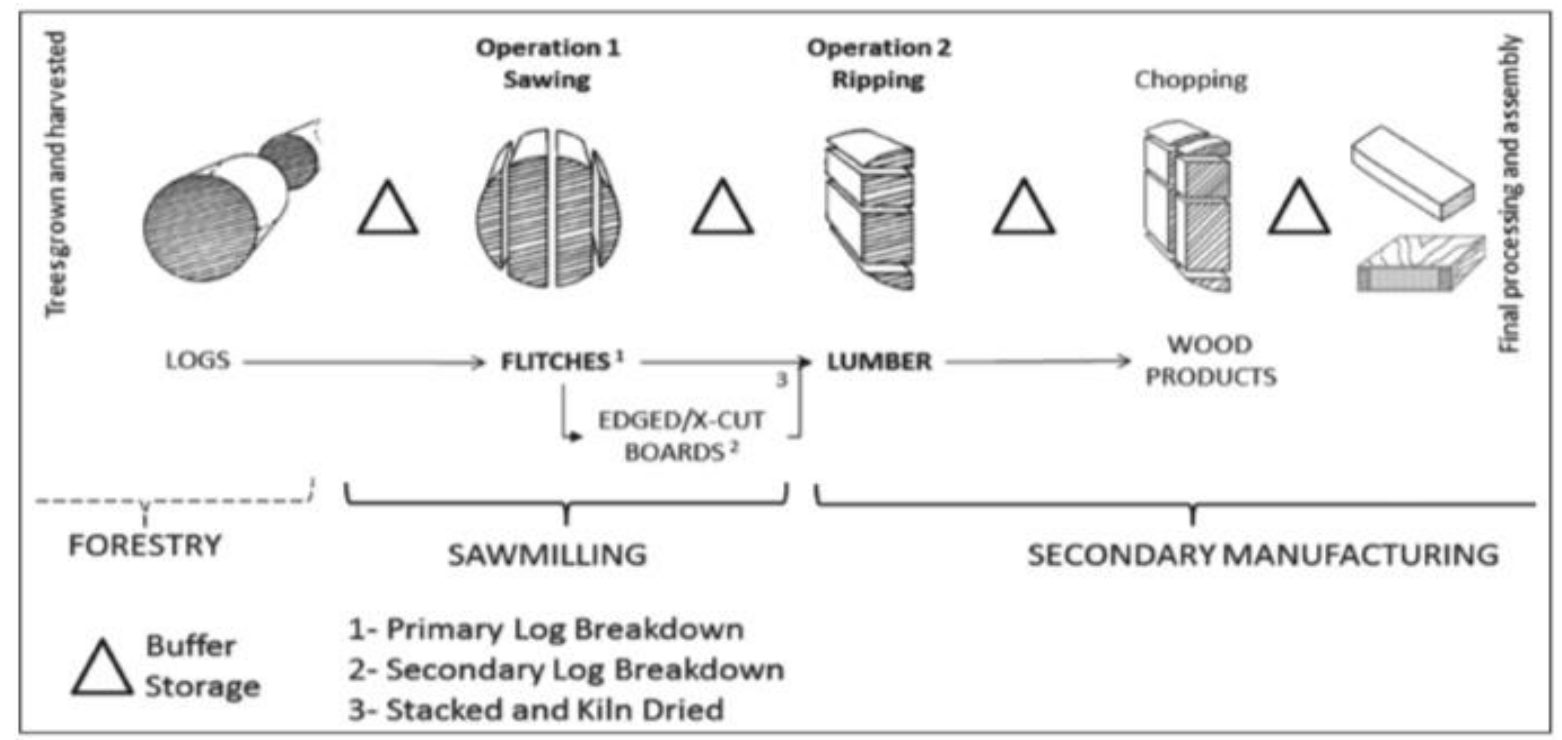

Fig. 1. Sawmilling production process (adapted from [28])

\subsection{Notation and Mathematical Modeling}

In this section, a notation and mathematical model formulation are presented. Component models that are formulated consist of objective function and constraints.

Notations:

$d$

$l$

$i$

$j$

$p$

Parameter:

$V F i_{i} ; V F i_{j}$

$P V i_{i} ; P V i_{j}$
: Diameters of logs

: Length of logs

: Sawn timber products (for main product)

: Sawn timber products (for side product)

: Cutting pattern 


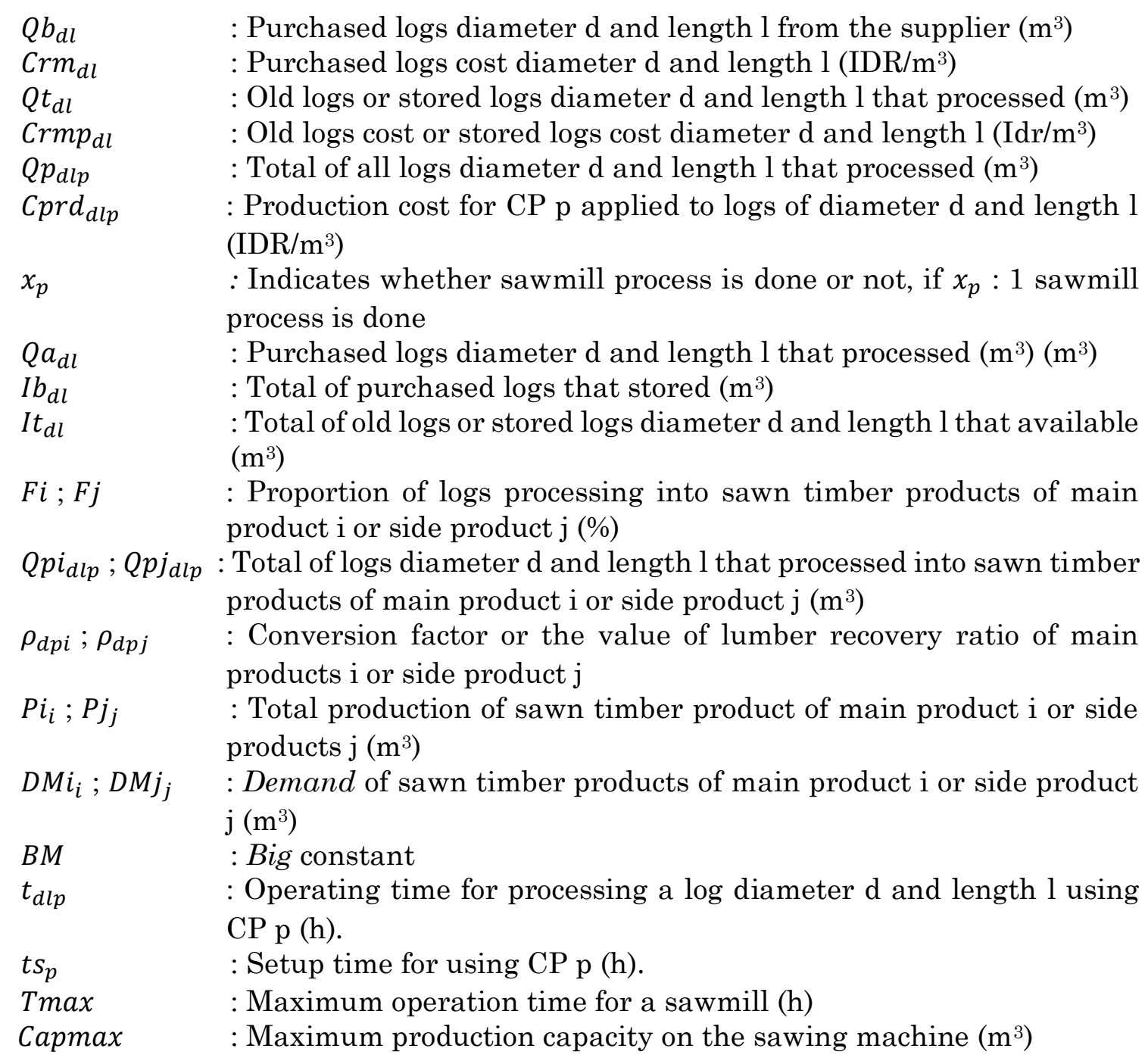

This mathematical model is used to optimize profit in production planning. Mathematical to describe this problem is as follows :

Equation (1) is the objective function of the problem to maximize profit. The components of the objective function are presented in equations (2)-(4). The equation describes the mathematical model of sales revenue or income. The mathematical model of raw material cost is explained in equation (3). The mathematical model of production cost is formulated in equation (4).

$$
\begin{aligned}
& \text { Max Z }=\text { In }-(\mathrm{CR}+\mathrm{CPr}) \\
& \text { In }=\sum_{i, j}\left(V F i_{i} P V i_{i}\right)+\left(V F j_{j} P V j_{j}\right) \\
& C R=\sum_{d, l} Q b_{d l} C r m_{d l}+Q t_{d l} C r m p_{d l} \\
& C P r=\sum_{d, l, p} Q p_{d l p} C p r d_{d l p}
\end{aligned}
$$

The constraint considers the availability of raw materials and inventory, log processing, and production process of main product and side product to meet the demand 
satisfaction. Constraint in the availability of raw materials and inventory is formulated in equations (5) and (6). Equation (7)-(13) describes the constraint of the availability of log processing. The capacity limit is shown in equation (14). The constraint of a mathematical model of production and demand satisfaction is formulated in equation (15)-(18).

$$
\begin{aligned}
& \sum Q b_{d l}=Q a_{d l}+I b_{d l} \quad \forall d, l \\
& I t_{d l} \geq Q t_{d l} \forall d, l \\
& \sum_{d, l, p} F i Q p_{d l p}=Q p i_{d l p} \\
& \sum_{d, l, p} F j Q p_{d l p}=Q p j_{d l p} \\
& \sum_{p, d} Q p i_{d l p} \rho_{d p i}=P i_{i} \quad \forall l, i \\
& \sum_{p, d} Q p j_{d l p} \rho_{d p j}=P j_{j} \forall l, j \\
& \sum_{p} Q p_{d l p}=Q t_{d l}+Q a_{d l} \forall d, l \\
& \sum_{d, l} Q p_{d l p} \leq B M x_{p} \quad \forall p \\
& \sum_{d, l, p} Q p_{d l p} t_{d l p}+\sum_{p \in P} t s_{p} x_{p} \leq \operatorname{Tmax} \\
& \sum_{d, l, p} Q p_{d l p} \leq \text { Capmax } \\
& P i_{i} \geq V F i_{i} \forall i \\
& P j_{j} \geq V F j_{j} \forall j \\
& V F i_{i}=D M i_{i} \forall i \\
& V F j_{j}=D M j_{j} \forall j
\end{aligned}
$$

\subsection{Case Study}

This research was conducted in Indonesia's Wood Industry. In formulating a mathematical model, the first step needed was to describe the industry's existing sawmill system. The log used is a teak log sent by KPH Perum Perhutani (State Forestry Company in Indonesia) as the supplier. The log used consisted of two sizes, namely AII with a 20-29 $\mathrm{cm}$ diameter and AIII with a diameter of $\geq 30 \mathrm{~cm}$. Several stages of the production process from log to sawn timber products, specifically: sawing using a Band Log Saw machine, ripping using a Band resaw machine, and chopping using a Cross-Cut machine. The stages of the production process can be seen in Fig. 1.

The logs used are AII and AIII logs. Each log was divided according to length, starting from 11 to 15.11 showed the sum of all logs that had a length of $50-90 \mathrm{~cm}, 12$ for logs with a length of 100-140 cm, 13 for logs with a length of $150-190 \mathrm{~cm}, 14$ for logs with a length of 200-240 cm, and 15 for logs with a length of $250-290 \mathrm{~cm}$. Then, there were ten sawn timber products, namely Jeblosan Board, Garden Furniture, Flooring, Decking, Skirting, Longstrip, and Parket Block, included in the main product. Then, Parket Stok, Reng, and List were included in the side product. 
Logs were processed using three machine units, namely PGM 1, PGM 2, and PGM 3 , with a total production capacity of $10,404 \mathrm{~m} 3$. Sawmill operation time was 8 hours per day for six working days a week. In a year, IK Brumbung's workday was 289 days. When processing logs into sawn timber products, there was a proportion value used in producing main products and side products. The proportion value of the use of logs into the main product was $80 \%$ of the total logs processed, and the side product was $20 \%$ of the total logs processed. Table 1 until Table 3 shows the data used in this study.

Table 1 . The availability of logs (AII)

\begin{tabular}{ccccc}
\hline \multirow{2}{*}{ Length } & \multicolumn{2}{c}{ Stored Logs } & \multicolumn{2}{c}{ Purchased Logs } \\
\cline { 2 - 5 } & Volume $\left(\mathrm{m}^{3}\right)$ & Cost (IDR) & Volume $\left(\mathrm{m}^{3}\right)$ & Cost (IDR) \\
11 & 6.030 & $2,328,042$ & 6.030 & $2,360,388$ \\
12 & 343.776 & $2,834,346$ & 343.776 & $3,291,644$ \\
13 & 270.993 & $3,035,619$ & 270.993 & $3,212,664$ \\
14 & 143.678 & $3,044,953$ & 143.678 & $3,231,399$ \\
15 & 21.588 & $3,199,186$ & 21.588 & $3,453,636$ \\
\hline
\end{tabular}

Table 2. The availability of logs (AIII)

\begin{tabular}{ccccc}
\hline \multirow{2}{*}{ Length } & \multicolumn{2}{c}{ Stored Logs } & \multicolumn{2}{c}{ Purchased Logs } \\
\cline { 2 - 5 } & Volume $\left(\mathrm{m}^{3}\right)$ & Cost (IDR) & Volume $\left(\mathrm{m}^{3}\right)$ & Cost (IDR) \\
\hline 11 & 221.770 & $4,446,927$ & 421.25 & $4,456,572$ \\
12 & 597.530 & $4,872,151$ & 1253.6 & $4,884,165$ \\
13 & 302.880 & $4,924,974$ & 1279.42 & $5,057,298$ \\
14 & 256.970 & $6,006,590$ & 1580.39 & $6,261,820$ \\
15 & 1.740 & $6,637,329$ & 188.19 & $6,733,965$ \\
\hline
\end{tabular}

Table 3. The demand for sawn timber products

\begin{tabular}{cccc}
\hline $\begin{array}{c}\text { Sawn Timber } \\
\text { Products }\end{array}$ & Volume $\left(\mathrm{m}^{3}\right)$ & $\begin{array}{c}\text { Sawn Timber } \\
\text { Products }\end{array}$ & Volume $\left(\mathrm{m}^{3}\right)$ \\
Jeblosan Board & 94.653 & RST Other & 5.248 \\
Garden Furniture & 82.729 & Parket Block & 192.120 \\
Decking & 121.711 & Parket Stok & 0 \\
Longstrip & 253.759 & Reng & 176.452 \\
Flooring & 1206.444 & List & 0 \\
\hline
\end{tabular}




\subsection{Sensitivity Analysis}

Sensitivity analysis is an analysis used to determine the impact of changes in some parameters in the production system's performance in generating the decision variable, so it can be known what parameters are sensitive to the model being built. In this research, local sensitivity analysis was done by only looking at changes in the model output to changes in input parameters around the specific value of $\mathrm{x}$. The method used was One-Ata-Time (OAT), or a method that analyzed changes in one parameter value. At the same time, the other parameter values were fixed [31]. In this research, sensitivity analysis was done by changing the volume of sawn timber products demand.

The 12 parameters were used to see the effect of changes in the volume of demand on the decision variable or output. Demand on parameter 1 decreased by $0.5 \%$ from the actual demand, parameter 2 decreased by $0.4 \%$, parameter 3 decrease by $0.3 \%$, parameter 4 decrease by $0.2 \%$, parameter 5 decrease by $0.1 \%$, parameter 6 decrease by $0.004 \%$, parameter 7 increase by $0.004 \%$, parameter 8 increase by $0,1 \%$, parameter 9 increase by $0.2 \%$, parameter 10 increase by $0.3 \%$, parameter 11 increase by $0.4 \%$, and parameter 12 increase by $0.5 \%$.

\section{Results and Discussion}

\subsection{Productions Planning with ILOG CPLEX}

This section describes the results of production planning to maximize profits. Table 4 shows the volume of sawn timber products produced from data processing using ILOG CPLEX. The volume indicated that all demands were met and additional production outside of demand for both the main products and the side products. This additional production later became a ready-stock product. From Table 4, it is known that the proportion of production of sawn timber products for main products and side products was appropriate where the company should produce more of the main products than the side products.

Table 4. The volume of sawn timber products produced

\begin{tabular}{cccc}
\hline Sawn Timber Products & Volume $\left(\mathrm{m}^{3}\right)$ & Sawn Timber Products & Volume $\left(\mathrm{m}^{3}\right)$ \\
\hline Jeblosan Board & 457.3707 & RST Other & 91.1818 \\
Garden Furniture & 181.4165 & Parket Block & 657.457 \\
Decking & 191.7778 & Parket Stok & 21.3076 \\
Longstrip & 372.4754 & Reng & 176.452 \\
Flooring & 1206.444 & List & 31.2195
\end{tabular}

After solving the model using ILOG CPLEX, the objective function's value was equal to $\mathrm{Rp} 74,406,574,908$ in a yearly planning horizon, as seen in Fig. 2. These results indicated that the model used gave a positive profit value. There was an increase in revenue from these results as much as $29 \%$, or equal to $\mathrm{Rp} 16,510,574,908$ from the actual conditions.

The proposed model's increase in income occurs due to the proposed model used in the optimal condition. It corresponds to where the proposed model, an additional constraint function regarding production capacity on the sawing machine, appeared. Besides, in actual condition, some demand for sawn timber products was not fulfilled. Therefore, using the proposed model, production planning is projected to increase processing logs' efficiency into sawn timber products in meeting demand. 


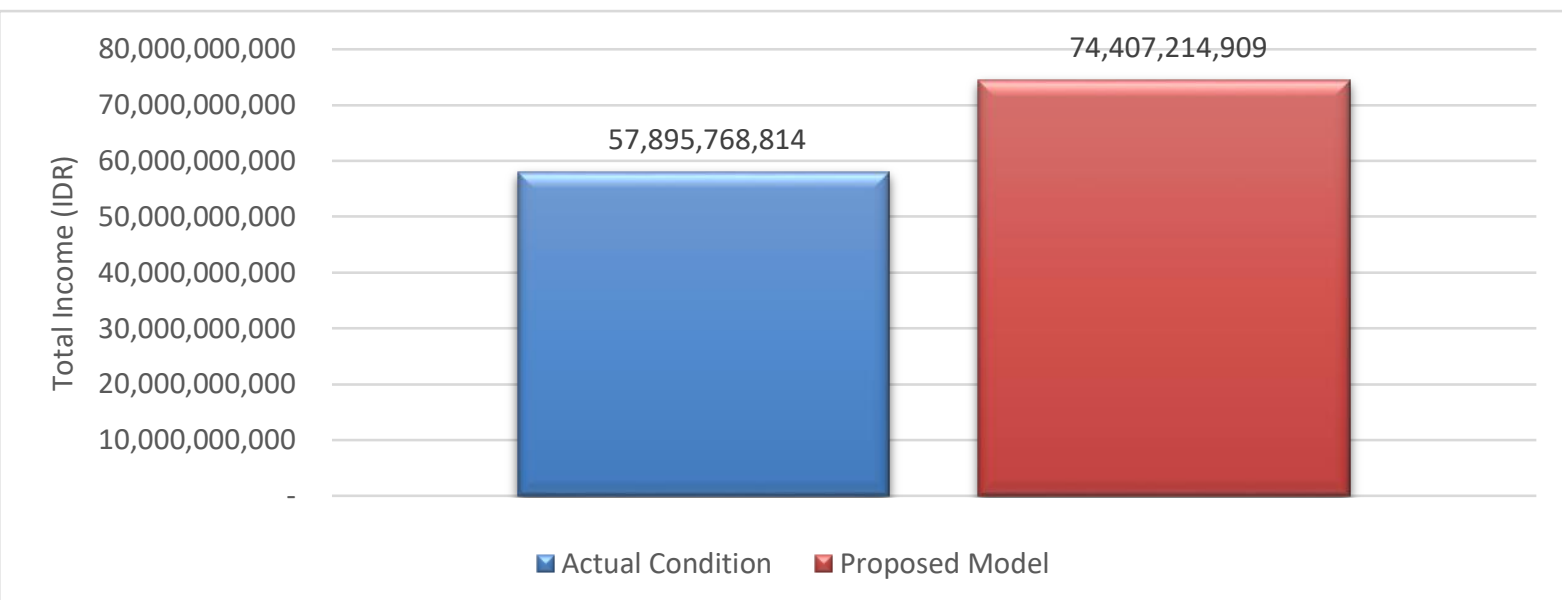

Fig. 2. Income (IDR) Comparison between the Actual Condition and Proposed Model

\subsection{Sensitivity analysis}

Fig. 3 shows a graph of changes in all sawn timber products' total volume for each parameter. The volume of sawn timber production used as a comparison is indicated in the initial parameters. There was a change in production volume for all sawn timber products in parameters $1,2,3,4,5,8,9,10,11$, and 12 . However, in parameters six and parameter 7 , the production volume did not change for all sawn timber products. These results indicate that the proposed model gives different results when the demand volume decreases by $0.005 \%$ and increase by $0.005 \%$. The model postulates different results when the demand volume is below the decrease of $0.005 \%$ and below the increase of $0.005 \%$. The graph above also shows that the change of production volume will move linearly as the parameter value change. Thus, it can be seen that the proposed model is sensitive to changes in demand above $0.004 \%$ and below $0.004 \%$.

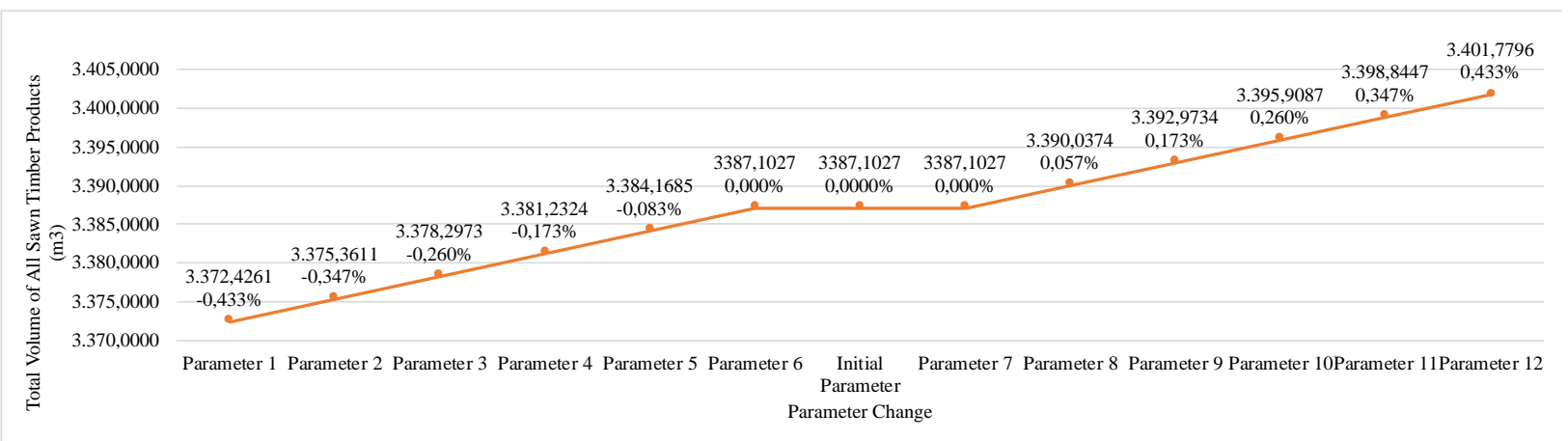

Fig. 3. Percentage Change in Production Volume of Sawn Timber Products

\section{Conclusion}

One of the sawmill industry's problems is to fulfill the demand by increasing the efficiency of using logs to maximize profit. In increasing the level of efficiency, optimizing production planning can be used. In this study, a model of Mixed-Integer Linear Programming for optimal production planning was proposed. This model has an objective function to maximize the profits obtained from calculations by considering the sale of sawn 
timber products, production costs, and the cost of purchasing logs. Then, production planning also considered the availability of raw materials, log processing, and production products to meet demand satisfaction. From the calculation results, the proposed model successfully integrated the factors above and also could solve problems in sawmill production planning, especially maximize the profit and meet the demand satisfaction for sawn timber products. Further research can be developed by considering each month's time period in a yearly planning horizon and exercising different cutting patterns in log processing into sawn timber products.

\section{Acknowledgments}

The authors would like to thank all those who have helped in this research, especially for Perum Perhutani for supporting and providing the data needed.

\section{References}

[1] N. Sari, E. Erniwati, and A. Hapid, "Sifat Mekanika Kayu Kemiri (Aleurites mollucana Willd) Asal Sulawesi Tengah Berdasarkan Arah Aksial," Jurnal Warta Rimba, vol. 3, 2015.

[2] F. Elijah and E. Isa, "Environmental Sustainability Impact of the Okobaba Sawmill Industry on some biogeochemistry characteristics of the Lagos Lagoon," Poultry, Fisheries \& Wildlife Sciences, pp. 1-19, 2015. http://dx.doi.org/10.4172/2375446X.1000131.

[3] W. R. Nyemba, A. Hondo, C. Mbohwa, and L. Madiye, "Unlocking economic value and sustainable furniture manufacturing through recycling and reuse of sawdust," Procedia Manufacturing, vol. 21, pp. 510-517, 2018. https://doi.org/10.1016/j.promfg.2018.02.151.

[4] F. P. Vergara, C. D. Palma, and H. Sepúlveda, "A comparison of optimization models for lumber production planning," Bosque, vol. 36, pp. 239-246, 2015. http://dx.doi.org/10.4067/S0717-92002015000200009.

[5] C. D. Palma and F. P. Vergara, "A Multiobjective Model for the Cutting Pattern Problem with Unclear Preferences," Forest Science, vol. 62, pp. 220-226, 2016. https://doi.org/10.5849/forsci.14-100.

[6] N. Vanzetti, D. Broz, G. Corsano, and J. M. Montagna, "An optimization approach for multiperiod production planning in a sawmill," Forest Policy and Economics, vol. 97, pp. 1-8, 2018. https://doi.org/10.1016/j.forpol.2018.09.001.

[7] R. Jegatheswaran, M. A. Aznor, R. Geetha, and C. Seng, "A review of different sawing and drying techniques used in processing small-diameter logs," Journal of Applied Sciences, vol. 13, pp. 341-347, 2013.

[8] E. Aghimien, O. Akinkuoroye, and O. Adams, "Assessment of wood waste generated in selected sawmills in Kajola local government area of Oyo state," Journal of Research in Forestry, Wildlife and Environment, vol. 12, 2020.

[9] J. Malik and G. Hopewell, "Sawing Recovery Of Several Sawmills In Jepara," Jurnal Penelitian Hasil Hutan, vol. 29, 2011. https://dx.doi.org/10.20886/jphh.2011.29.4.331-342.

[10] F. Cid Yañez, J.-M. Frayret, A. Rousseau, and F. Léger, "Simulation of Lumber Production Planning using Software Agents: a Case Study," 2008.

[11] R. Okai and O. Boateng, "Analysis of sawn lumber production from logging residues of branchwood of Aningeria robusta and Terminalia ivorensis," European Journal 
of Forest Research, vol. 126, pp. 385-390, 2007. https://doi.org/10.1007/s10342-0060157-z.

[12] D. Ekhuemelo, "Evaluation of Lumber Recovery and Waste Generation in Selected Sawmills in Three Local Government Areas of Benue State, Nigeria," vol. 20, pp. 62-68, 2015.

[13] A. D. Laksono, T. Susdiyanti, and K. Bintani, "Produktivitas dan rendemen industri penggergajian kayu di kecamatan cigudeg kabupaten bogor," Jurnal Nusa Sylva, vol. 16, pp. 5-58, 2018.

[14] R. Okai, C. Tanaka, and Y. Iwasaki, "Influence of mechanical properties and mineral salts in wood species on tool wear of high-speed steels and stellite-tipped tools - Consideration of tool wear of the newly developed tip-inserted band saw," Holz als Roh- und Werkstoff, vol. 64, pp. 45-52, 2006. https://doi.org/10.1007/s00107-005-0015-6.

[15] B. Szyszka and K. Rozmiarek, "Mathematical Modeling of Primary Wood Processing," AIP Conference Proceedings, vol. 1048, pp. 534-537, 2008. https://doi.org/10.1063/1.2990980.

[16] A. Rahman, S. Yella, and M. Dougherty, "Simulation and optimisation techniques for sawmill yard operation : A literature review," Journal of Intelligent Learning Systems and Applications, vol. 6, pp. 21-34, 2014. https://doi.org/10.4236/jilsa.2014.61003.

[17] S. Maturana, E. Pizani, and J. Vera, "Scheduling production for a sawmill: A comparison of a mathematical model versus a heuristic," Computers \& Industrial Engineering, vol. 59, pp. 667-674, 2010. https://doi.org/10.1016/j.cie.2010.07.016.

[18] S. Caldera and H. Amarasekera, "Investigation of Sawmill Management and Technology on Waste Reduction at Selected Sawmills in Moratuwa, Sri Lanka," Journal of Tropical Forestry and Environment, vol. 5, 2015. https://dx.doi.org/10.31357/jtfe.v5i1.2499.

[19] U. Buehlmann, R. E. Thomas, and X. Zuo, "Cost minimization through optimized raw material quality composition," Robotics and Computer-Integrated $\begin{array}{lllll}\text { Manufacturing, } & \text { vol. } & 27, & \text { pp. } & 746-754,\end{array}$ https://doi.org/10.1016/j.rcim.2010.12.013.

[20] J. Frank Eshun, J. Potting, and R. Leemans, "Wood waste minimization in the timber sector of Ghana: a systems approach to reduce environmental impact," Journal of Cleaner Production, vol. 26, pp. 67-78, 2012. https://doi.org/10.1016/j.jclepro.2011.12.025.

[21] M. Hisjam, A. D. Guritno, H. Simon, and S. D. Tandjung, "A framework for the development of sustainable supply chain management for business sustainability of export-oriented furniture industry in Indonesia (A case study of teak wooden furniture in Central Java Province)," in Proc. of the 1st International Conference on Industrial Engineering and Service Science, 2011.

[22] M. Kazemi Zanjani, D. Ait-Kadi, and M. Nourelfath, "Robust production planning in a manufacturing environment with random yield: A case in saw mill production planning," European Journal of Operational Research, vol. 201, pp. 882-891, 2010. https://doi.org/10.1016/j.ejor.2009.03.041.

[23] N. E. D. Astuti, L. Linawati, and T. Mahatma, "Penerapan Model Linear Goal Programming Untuk Optimasi Perencanaan Produksi," 2013.

[24] M. Side and V. Erol, "Applying Quantum Optimization Algorithms for Linear Programming," 2017. https://dx.doi.org/10.20944/preprints201703.0238.v3. 
[25] P. P. Alvarez and J. R. Vera, "Application of Robust Optimization to the Sawmill Planning Problem," Annals of Operations Research, vol. 219, pp. 457-475, 2014. https://doi.org/10.1007/s10479-011-1002-4.

[26] R. R. Farrell and T. C. Maness, "A relational database approach to a linear programming-based decision support system for production planning in secondary wood product manufacturing," Decision Support Systems, vol. 40, pp. 183-196, 2005. https://doi.org/10.1016/j.dss.2004.02.001.

[27] S. Koch, S. König, and G. Wäscher, "Integer linear programming for a cutting problem in the wood-processing industry: a case study," International Transactions in Operational Research, vol. 16, pp. 715-726, 2009. https://doi.org/10.1111/j.14753995.2009.00704.x.

[28] B. G. Lindner, P. J. Vlok, and C. B. Wessels, "Determining optimal primary sawing and ripping machine settings in the wood manufacturing chain," Southern Forests: a Journal of Forest Science, vol. 77, pp. 191-201, 2015. https://doi.org/10.2989/20702620.2014.1001678.

[29] D. Broz, N. Vanzetti, G. Corsano, and J. M. Montagna, "Goal programming application for the decision support in the daily production planning of sawmills," Forest Policy and Economics, vol. 102, pp. 29-40, 2019. https://doi.org/10.1016/j.forpol.2019.02.004.

[30] L. Huang and J. Yang, "Location-distribution of cruise ship supply logistics distribution centre considering time window," Systems Science \& Control $\begin{array}{lllll}\text { Engineering, } & \text { vol. } & 7, & \text { pp. } & 338-345,\end{array}$ https://doi.org/10.1080/21642583.2019.1674221.

[31] F. Pianosi, K. Beven, J. Freer, J. W. Hall, J. Rougier, D. B. Stephenson, et al., "Sensitivity analysis of environmental models: A systematic review with practical workflow," Environmental Modelling \& Software, vol. 79, pp. 214-232, 2016. https://doi.org/10.1016/j.envsoft.2016.02.008. 